\title{
TFF1 is Differentially Expressed in Stationary and Migratory Rat Gastric Epithelial Cells (RGM-1) after in Vitro Wounding: Influence of TFF1 RNA Interference on Cell Migration
}

\author{
Ting Fu Hubert Kalbacher ${ }^{\mathrm{b}}$ Werner Hoffmann ${ }^{\mathrm{a}}$ \\ aInstitute of Molecular Biology and Medicinal Chemistry, Otto-von-Guericke-University Magdeburg, \\ 'Interfaculty Institute of Biochemistry, Eberhard-Karls-University Tübingen, Germany
}

\section{Key Words}

Cell migration $•$ Wound healing $•$ Mucosal injury $\bullet$ Restitution $\bullet$ TFF1 $•$ Trefoil factor $•$ Gastrokine $2 \cdot$ Survivin $•$ LGR5 $・$ EMT $・$ siRNA

\begin{abstract}
Background/Aims: The trefoil factor family (TFF) peptide TFF1 is typically secreted by gastric surface mucous cells. These cells are also the major players in gastric restitution, i.e., repair of the stomach mucosa by cell migration after injury. Methods: An established in vitro model of gastric restitution, i.e., migration of the non-transformed rat gastric cell line RGM-1 after scratch wounding, was investigated by expression profiling of selected genes from separated stationary and migratory cells. Also semi-quantitative immunocytochemistry was performed. Furthermore, RGM-1 cells were transfected with stealth RNAi $i^{\mathrm{TM}}$ duplexes targeting Tff1 and relative cell migration rates were analyzed. Results: Surprisingly, Tff1 expression was upregulated in migratory cells. No unequivocal signs of the epithelial-mesenchymal transition were detectable in migratory cells. Transfection of RGM-1 cells with Tff1-siRNAi duplexes negatively influenced migration of these cells. Conclusion: This clearly points to a function of Tff1 as a motogen. A possible up-regulation of TFF1 synthesis in migratory surface mucous cells also in vivo would be an ideal mechanism to specifically enhance gastric restitution only where topologically needed and to minimize eventual negative side effects of TFF1 such as cell scattering and invasiveness.
\end{abstract}


Fu/Kalbacher/Hoffmann: TFF1 and Cell Migration

\section{Introduction}

The peptide TFF1 (previously named pS2), together with TFF2 and TFF3, is a member of the trefoil factor family (TFF; for reviews, see refs. [1-4]). TFF1 is typically secreted by gastric surface mucous cells (SMCs) together with the mucin MUC5AC [5, 6]. Human TFF1 contains 7 cysteine residues and exists in different molecular forms, such as a disulfidelinked TFF1-gastrokine 2 (GKN2) heterodimer $[7,8]$ and probably also as a monomer and a homodimer $[9,10]$. Recombinant TFF1 has been reported to form monomers [11] or homodimers $[12,13]$.

Tff1 is responsible for a number of pleiotropic effects (for review, see [2]). Recombinant TFF1 is motogenic, with the Cys ${ }^{58}$ homodimer being more active than the TFF1 monomer, i.e., the $\operatorname{Ser}^{58}$ mutant $[14,15]$. Furthermore, anti-proliferative and anti-apoptotic effects [16] as well as a pro-apoptotic activity have been reported for recombinant TFF1 [17]. TFF1 also acts as a pro-angiogenic factor [18]. Stable expression of TFF1 induced scattering and invasiveness of cells [19-21] and increased anchorage-independent growth of premalignant adenoma cells in soft agar [22]. Thus, TFF1 has been discussed as a tumor progression factor $[23,24]$.

Tff1-deficient mice (Tff1 ${ }^{\mathrm{K}}$ ) obligatory develop antropyloric adenoma, and $30 \%$ progress to gastric carcinomas [25]. Here, the loss of Tff1 typically leads to an inflammatory response followed by the classical dysplasia-adenocarcinoma sequence [26]. In line with this, celecoxib, a selective Cox- 2 inhibitor and non-steroidal anti-inflammatory drug disturbed the integrity of the adenoma by promoting ulceration and inflammation [26, 27]. Moreover, chemically induced tumorigenesis in Tff ${ }^{\mathrm{KO}}$ mice led to higher tumor incidence, e.g., in the mammary gland when compared with the wild-type animals [21]. This clearly showed that TFF1 does not exhibit oncogenic properties but rather reduces tumor development [21]. Tff $1^{\mathrm{KO}}$ mice also show dysregulated gastric self-renewal with an expanded SMC population at the expense of parietal cells in the fundic units [28] and amplification of SMCs and antral gland cells in the antral units [29]. Thus, TFF1 influences cell differentiation as also shown for the respiratory tract $[2,21,30]$. Tff 1 deficiency has also been demonstrated to activate the unfolded protein response indicating a possible role for TFF1 in protein folding and/or secretion [31].

In contrast, transgenic mice that over-express Tff1 have an increased resistance to intestinal damage [32]. Intragastric administration of Tff1 by a genetically modified Lactococcus lactis also prevented induced colitis in mice [33].

TFF1 expression is dysregulated in inflammatory diseases and many neoplastic conditions (for reviews, see refs. [1, 3, 4, 24, 34]. For example, it is ectopically expressed in distal ductular and surface elements of the ulcer-associated cell lineage (UACL) [35, 36]. In contrast, TFF1 is down-regulated in the neoplastic human stomach [34].

Gastric SMCs, which are the typical source of TFF1, originate from progenitor cells of the isthmus by self-renewal (for reviews, see $[37,38]$ ) and are the major players during "restitution", i.e., the rapid repair of superficial lesions by cell migration (for reviews, see refs. $[39,40]$. Restitution represents one component of the complex network of gastric mucosal defense mechanisms, which are also involved in the healing of gastric ulcers (for reviews, see ref. [41, 42]). Restitution is strictly dependent on the glycolytic pathway [43] and TFF peptides are known to enhance mucosal restitution (for review, see ref. [44]). The non-transformed rat gastric cell line RGM-1 [45] is a well-established in vitro model for gastric restitution $[46,47,48]$.

In the past, we have developed a sensitive method for analyzing the gene expression of separated stationary and migratory cells after in vitro wounding [49]. Here, we apply this method to analyze systematically RGM-1 cells. Surprisingly, we found that Tff1 expression is up-regulated in migratory cells. 


\section{Materials and Methods}

Culture of RGM-1 cells

The non-transformed rat gastric epithelial cell line RGM-1 [45] (kindly provided by Dr. S. J. Hagen, Boston, USA) was maintained in $75-\mathrm{cm}^{2}$ cell culture flasks with filter caps (Greiner, Frickenhausen, Germany) at $37^{\circ} \mathrm{C}$ in a humidified atmosphere with $5 \%(\mathrm{v} / \mathrm{v}) \mathrm{CO}_{2}$. Dulbecco's modified Eagles medium (DMEM) with $4.5 \mathrm{~g} / \mathrm{L}$ glucose (GE Healthcare Life Sciences, USA) was routinely used as cell culture medium and supplemented with $1 \%$ (v/v) 100x non-essential amino acids, $1 \mathrm{mM}$ sodium pyruvate (both from Biochrom, Berlin, Germany), 2 mM glutamine (Life Technologies GmbH, Darmstadt, Germany), and 10\% (v/v) fetal calf serum (FCS; GE Healthcare Life Sciences, USA). For the migration experiments, cells between the 10th and 20th sub-cultivation were used. Before scratch-wounding, cultures were incubated in serum-free, supplemented growth medium for 12-15 h.

\section{Anti-mTff1 antiserum}

A polyclonal rabbit antiserum was generated against the synthetic peptide FHPMAIENTQEEECPF representing the $\mathrm{C}$-terminus of mouse Tff1. This sequence has already been used successfully as antigenic determinant [28]. The peptide was purified using reversed phase-HPLC and its identity was confirmed by MALDI-MS. The peptide was coupled to keyhole limpet hemocyanin (KLH) via glutaraldehyde and used to immunize a rabbit (Charles River Laboratories, Sulzfeld, Germany). The corresponding antiserum was termed anti-mTff1-1 and used for immunocytochemistry (1:500 dilution). Affinity purification was performed as previously described [50].

The specificity of the staining with anti-mTff1-1 was tested by competition with the corresponding synthetic peptide, i.e., $1 \mathrm{~mL}$ anti-mTff1-1 antiserum (1:500 dilution) was pre-adsorbed with $10 \mu \mathrm{g}$ synthetic peptide FHPMAIENTQEEECPF at $4^{\circ} \mathrm{C}$ overnight and then used for immunocytochemistry. Methods used for Western blot analysis of tissue extracts have previously been described [8].

\section{Immunocytochemistry after in vitro wounding}

RGM-1 cells were detached with trypsin/EDTA (0.05\% trypsin and 0.53 mM EDTA, Life Technologies $\mathrm{GmbH}$, Darmstadt, Germany) from the culture flasks and re-suspended in fully supplemented growth medium (plus 10\% v/v FCS). Sterile glass cover slips (22 x 22 mm, Gerhard Menzel GmbH, Braunschweig, Germany) were first placed in 6-well plate (Greiner Bio-One GmbH, Frickenhausen, Germany). Then $4.5 \mathrm{x}$ $10^{5}$ cells were seeded in each well and cultured with $2.5 \mathrm{~mL}$ fully supplemented growth medium (plus $10 \%$ $\mathrm{v} / \mathrm{v}$ FCS). Once the cells were confluent, the medium was replaced with $2.5 \mathrm{~mL}$ serum free medium. After $12 \mathrm{~h}$ incubation, the cell monolayer was scratched under sterile conditions with Cell Lifter (19 mm blade, Corning ${ }^{\circledR}$ Inc. Costar, Tewksburg/MA, USA). Routinely, 2 wound sites ( 18-19 mm) were created on each cover slip. The wounded cell cultures were carefully rinsed with serum free medium to remove residual cell debris. Cells were further incubated in $2.5 \mathrm{~mL}$ fresh serum free medium for $24 \mathrm{~h}$ and were then used for immunocytochemistry.

The cells on the glass cover slips were fixed with cold methanol at $-20^{\circ} \mathrm{C}$ for $5 \mathrm{~min}$ in the 6-well plates.

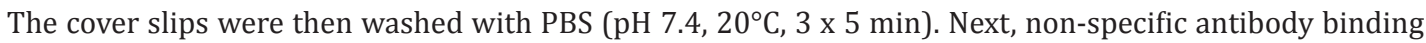
sites were blocked with blocking buffer: PBS (pH 7.4), 10\% goat serum (v/v) (PAA, GE Healthcare Life Sciences, Piscataway/NJ, USA), $0.3 \%$ (v/v) Triton-X100, and $0.1 \%(v / v) \mathrm{NaN}_{3}$ (both from Sigma-Aldrich Chemie, Taufkirchen, Germany) at $20^{\circ} \mathrm{C}$ for $1 \mathrm{~h}$. The primary antibody anti-mTff1-1 was diluted (1:500) in blocking buffer. Incubation with the primary antibody was carried out at $4^{\circ} \mathrm{C}$ overnight. Then, the cover slips were rinsed with $\mathrm{PBS}\left(\mathrm{pH} 7.4,20^{\circ} \mathrm{C}, 3 \times 5 \mathrm{~min}\right.$ ), incubated with the secondary antibody (Cy3-labeled antirabbit-IgG F(ab') ${ }_{2}$ fragment from sheep antiserum, Sigma-Aldrich Chemie, Taufkirchen, Germany; dilution: 1:200 in blocking buffer) at $20^{\circ} \mathrm{C}$ for $1 \mathrm{~h}$ (this incubation and all subsequent steps were carried out in the dark) and rinsed again with $\mathrm{PBS}\left(\mathrm{pH} 7.4,20^{\circ} \mathrm{C}, 2 \times 5 \mathrm{~min}\right)$.

The cell nuclei were stained with 4',6-diamidino-2-phenylindole dihydrochloride (DAPI, SigmaAldrich Chemie, Taufkirchen, Germany) at $20^{\circ} \mathrm{C}$ for $5 \mathrm{~min}$ using a DAPI stock solution (0.1 $\left.\mathrm{mg} / \mathrm{ml}\right)$ in a 1:1000 dilution (in PBS, pH 7.4). Subsequently, the cover slips were rinsed twice with PBS (pH 7.4, 20 ${ }^{\circ} \mathrm{C}$ ) for $5 \mathrm{~min}$ and once with ultrapure water for $5 \mathrm{~min}$. Finally, the cover slips were embedded on the microscope slides using fluorescent mounting medium (DAKO Deutschland GmbH, Hamburg, Germany). 
Table 1. Sequences of the stealth RNAi ${ }^{\mathrm{TM}}$ duplexes

\begin{tabular}{llllll}
\hline & Cat. No. & & Sequence & Nucleotide \\
Name & positions & GC\% \\
\hline rTff1-siRNA1 & Tff1RSS350528 & sense & CAUGGUGCUUCCGACCUCUGGUCAU & $218-242$ & $56.01 \%$ \\
& & anti-sense & AUGACCAGAGGUCGGAAGCACCAUG & & Hi GC \\
rTff1-siRNA2 & Tff1RSS350530 & sense & CCAGAACCAGGAAGAAACAUGUGCC & $93-117$ & $52.00 \%$ \\
& & anti-sense & GGCACAUGUUUCUUCCUGGUUCUGG & Hi GC \\
rTff1-siRNA3 & \multirow{2}{*}{ Tff1RSS350529 } & sense & GCAAGAAGAAGAAUGUCCCUUCUAA & 252-276 & $40.00 \%$ \\
& & anti-sense & UUAGAAGGGACAUUCUUCUUCUUGC & Low GC \\
Negative Control & \multirow{2}{*}{$12935-114$} & sense & GGUAGGUGAGUGUACAGACGCAAUA & $50.00 \%$ \\
& & anti-sense & UAUUGCGUCUGUACACUCACCUACC & Hi GC \\
\hline
\end{tabular}

The slides were photographed with an Axiophot microscope equipped with an AxioCam digital camera (Carl Zeiss MicroImaging GmbH, Jena, Germany). The following filter sets were used: 01 (DAPI; excitation: BP 365/12, beamsplitter: FT 395, emission: LP 397) and 15 (Cy3; excitation: BP 546/12, beamsplitter: FT 580, emission: LP 590). The images were processed with the AxioVision software package (Carl Zeiss MicroImaging GmbH, Jena, Germany).

For quantitative Tff1 analysis, pictures were taken (objective: 20x) which always contained both stationary and migratory cell regions. Then, for each picture the total Tff 1 immunofluorescence signal (Cy3 label) was analyzed by measuring the integrated pixel intensity within a rectangular standardized area of stationary and migratory front cells, respectively, using the GeneTools analysis software (Syngene Bioimaging, Synoptics Ltd., Cambridge, UK) which automatically corrected for the background. Always pairs of standardized areas (within the stationary region and the migratory front, respectively) parallel to the scratch wound were analyzed from the same picture (see Fig. 2A). This value obtained was divided by the number of cells (after DAPI staining of cell nuclei) in order to calculate the relative Tff1 immunofluorescence per cell.

RNA interference and scratch wound assays

Three different non-overlapping stealth RNAi ${ }^{\mathrm{TM}}$ duplexes designed for rat Tff1 (NM_057129.1) were purchased from Invitrogen (Life Technologies Corporation, Carlsbad/CA, USA): site 1 (Tff1-siRNA1), site 2 (Tff1-siRNA2), and site 3 (Tff1-siRNA3). Sequence information for the three stealth RNAi ${ }^{\mathrm{TM}}$ duplexes as well as the corresponding stealth $\mathrm{RNAi}^{\mathrm{TM}}$ negative control used in this study is provided in Table 1. Stealth RNAi ${ }^{\mathrm{TM}}$ compounds are 25-mer dsRNA molecules containing proprietary chemical modifications that enhance nuclease stability and reduce off-target effects by limiting sense strand activity [51].

One day before transfection, RGM-1 cells were seeded in $100 \mathrm{~mm}$ cell culture dishes (Greiner Bio-One $\mathrm{GmbH}$, Frickenhausen, Germany) at $2 \times 10^{6}$ cell density in fully supplemented growth medium (plus $10 \% \mathrm{v} / \mathrm{v}$ FCS). This medium was replaced by $15 \mathrm{~mL}$ Opti-MEM (Life Technologies GmbH, Darmstadt, Germany) $4 \mathrm{~h}$ before transfection. Cells were then transfected with either $125 \mathrm{nM}$ stealth RNAi ${ }^{\mathrm{TM}}$ for Tff1 or stealth RNAi ${ }^{\mathrm{TM}}$ negative control, respectively, using the cationic lipid-based transfection reagent Lipofectamine 2000 (Life Technologies GmbH, Darmstadt, Germany) at $1 \mu \mathrm{g} / \mathrm{mL}$ according to the manufacturer's instructions. After 8 hours, $10 \%$ FCS was added to the transfection mix. At 24 hours after transfection, the medium was replaced with normal growth medium, fully supplemented including $10 \%(\mathrm{v} / \mathrm{v})$ FCS. Cells were cultured for another 48-72 h. Once the cells were confluent, the medium was replaced with $15 \mathrm{~mL}$ of serum free medium. After $12 \mathrm{~h}$ incubation, the cell monolayers were scratched under sterile conditions with Cell Lifter (19 mm blade, Corning ${ }^{\circledR}$ Inc. Costar, USA).

Routinely, 5 rectangular wound zones $(\sim 5 \times 40-80 \mathrm{~mm})$ were created on each culture dish according to the pattern marked on the outer bottom surface of the cell culture dishes. The scratch wounded cells were carefully rinsed (3-5 times) with $37^{\circ} \mathrm{C}$ serum free medium to remove residual cell debris and then further incubated in $15 \mathrm{~mL}$ of fresh serum free medium for $24 \mathrm{~h}$. The wound areas were photographed immediately $(0 \mathrm{~h})$ and $24 \mathrm{~h}$ after the scratch at the exactly same positions according to the pattern on the bottom. The growth area between the two time points ( $0 \mathrm{~h}$ and $24 \mathrm{~h})$ was analyzed using Adobe Photoshop 7.0 by counting the pixel numbers. 
Fu/Kalbacher/Hoffmann: TFF1 and Cell Migration

Table 2. Oligodeoxynucleotides used for RT-PCR analysis and calculated size of the products. Actb: $\beta$-actin; Acta2: $\alpha$-smooth muscle actin; Birc5: survivin; Ccna2: cyclin A2; Gkn2: gastrokine 2; Muc16: mucin 16; Pgc: pepsinogen C; Sdf1: stromal cell-derived factor-1/Cxcl12; Vim: vimentin

\begin{tabular}{|c|c|c|c|c|c|c|c|c|}
\hline Genes & Accession No. & Primer No. & Sequence & $\begin{array}{c}\text { Nucleotide } \\
\text { positions }\end{array}$ & $\mathrm{T}_{\mathrm{m}}$ & Cycles & Size (bp) & $\begin{array}{l}\text { Intron- } \\
\text { spanning }\end{array}$ \\
\hline Acta2 & NM_031004 & $\begin{array}{l}\text { MB671 } \\
\text { MB672 }\end{array}$ & $\begin{array}{l}\text { CGATAGAACACGGCATCATCAC } \\
\text { TCCAGAGCGACATAGCACAG }\end{array}$ & $\begin{array}{l}257-278 \\
713-694\end{array}$ & $60^{\circ} \mathrm{C}$ & 25 & 457 & yes \\
\hline Ccna2 & NM_053702.3 & $\begin{array}{l}\text { MB661 } \\
\text { MB662 }\end{array}$ & $\begin{array}{l}\text { TGTCTGTGTTAAGAGGAAAGC } \\
\text { GTGAAGGTCCATGAGACAAG }\end{array}$ & $\begin{array}{c}796-816 \\
1244-1225\end{array}$ & $57^{\circ} \mathrm{C}$ & 31 & 449 & yes \\
\hline Survivin/Birc5 & NM_022274.1 & $\begin{array}{l}\text { MB2272 } \\
\text { MB2273 }\end{array}$ & $\begin{array}{l}\text { CCTGATTTGGCCCAGTGTT } \\
\text { TCATCTGACGTCCAGTTTCG }\end{array}$ & $\begin{array}{l}158-176 \\
563-544\end{array}$ & $60^{\circ} \mathrm{C}$ & 30 & 406 & yes \\
\hline Tff1 & NM_057129.1 & $\begin{array}{l}\text { MB1547 } \\
\text { MB1548 }\end{array}$ & $\begin{array}{l}\text { CCCAGAACCAGGAAGAAACA } \\
\text { ACCAGTTCTCTCGGATGGAC }\end{array}$ & $\begin{array}{c}92-111 \\
297-278\end{array}$ & $60^{\circ} \mathrm{C}$ & 30 & 206 & yes \\
\hline Gkn2 & NM_001039686.1 & $\begin{array}{l}\text { MB2164 } \\
\text { MB2165 }\end{array}$ & $\begin{array}{l}\text { ATGCTCTTCCACCACCATTT } \\
\text { GCAGATAGAGATCCCCAGGA }\end{array}$ & $\begin{array}{l}202-221 \\
568-549\end{array}$ & $60^{\circ} \mathrm{C}$ & 35 & 367 & yes \\
\hline Tff3 & NM_013042.1 & $\begin{array}{l}\text { MB1551 } \\
\text { MB1552 }\end{array}$ & $\begin{array}{l}\text { GACTCCAGCATCCCAAATGT } \\
\text { GCAGATCAGGGGTGAGTGTT }\end{array}$ & $\begin{array}{l}219-238 \\
370-351\end{array}$ & $60^{\circ} \mathrm{C}$ & 35 & 152 & yes \\
\hline Pgc & NM_133284.2 & $\begin{array}{l}\text { MB1169 } \\
\text { MB1170 }\end{array}$ & $\begin{array}{l}\text { TGGGTGTCTTCTGTCTACTGC } \\
\text { GCATGACGAGCAGAGAGGT }\end{array}$ & $\begin{array}{l}361-381 \\
925-907\end{array}$ & $60^{\circ} \mathrm{C}$ & 32 & 565 & yes \\
\hline Muc16 & XM_235886.7 & $\begin{array}{l}\text { MB2242 } \\
\text { MB2243 }\end{array}$ & $\begin{array}{l}\text { CCCCTAGTGGCTATGTACCG } \\
\text { AGGGTAGGTTGGTGATGGTG }\end{array}$ & $\begin{array}{l}314-333 \\
766-747\end{array}$ & $60^{\circ} \mathrm{C}$ & 38 & 453 & yes \\
\hline Cxcl12/Sdf-1 & NM_001033882.1 & $\begin{array}{l}\text { MB954 } \\
\text { MB955 }\end{array}$ & $\begin{array}{l}\text { ATCAGTGACGGTAAGCCAGT } \\
\text { GTAGCAAACTGCAAAGCAAG }\end{array}$ & $\begin{array}{l}133-152 \\
504-485\end{array}$ & $57^{\circ} \mathrm{C}$ & 30 & 372 & yes \\
\hline Lgr5 & NM_001106784.1 & $\begin{array}{l}\text { MB1151 } \\
\text { MB1152 }\end{array}$ & $\begin{array}{l}\text { ACTGGAGCAAAGATCTCGTC } \\
\text { TTATTCCGGGCTAAGTTCAG }\end{array}$ & $\begin{array}{l}1006-1025 \\
1226-1207\end{array}$ & $57^{\circ} \mathrm{C}$ & 35 & 221 & yes \\
\hline Vim & NM_031140.1 & $\begin{array}{l}\text { MB673 } \\
\text { MB674 }\end{array}$ & $\begin{array}{l}\text { TTTCCAAGCCTGACCTCAC } \\
\text { GAGAAATCCTGCTCTCCTCC }\end{array}$ & $\begin{array}{c}859-877 \\
1317-1298\end{array}$ & $60^{\circ} \mathrm{C}$ & 30 & 459 & yes \\
\hline Actb/ $\beta$-Actin & NM_031144.3 & $\begin{array}{l}\text { MB2158 } \\
\text { MB2159 }\end{array}$ & $\begin{array}{l}\text { AAGTACCCCATTGAACACGG } \\
\text { CAGCTCAGTAACAGTCCGC }\end{array}$ & $\begin{array}{c}280-299 \\
1225-1207\end{array}$ & $60^{\circ} \mathrm{C}$ & 25 & 946 & yes \\
\hline Actb promoter & NW_047369.2 & $\begin{array}{l}\text { MB1510 } \\
\text { MB1511 }\end{array}$ & $\begin{array}{l}\text { TTCCTCAATCTCGCTTTCTC } \\
\text { GGTTTTATAGGACGCCACAG }\end{array}$ & $\begin{array}{l}28641-28660 \\
28849-28830\end{array}$ & $57^{\circ} \mathrm{C}$ & 38 & 209 & -- \\
\hline
\end{tabular}

Isolation of stationary and migratory cells, RT-PCR analysis

After being photographed at $24 \mathrm{~h}$, the cells were sorted for RT-PCR analysis by detaching first the "stationary cells" as described previously in detail [49]. RNA isolation was performed using $450 \mu \mathrm{L}$ lysis buffer from the ISOLATE I (or II) RNA mini Kit (Bioline GmbH, Germany) according to the manufacturer's instructions.

Then, all remaining stationary cells as well as the migratory cells close to the stationary cells were removed using a 4-5 $\mathrm{mm}$ fragment of double edge stainless-steel razor blades as previously described $[49,52]$. The remaining cells were rinsed gently with $37^{\circ} \mathrm{C}$ serum free medium $(\sim 5$ times), so that only a population of pioneer cells were left over (i.e., about 10 rows of cells directly behind the migratory front). After a short rinse with PBS ( $\left.\mathrm{pH} 7.4,20^{\circ} \mathrm{C}\right)$, total RNA was also isolated from these "migratory cells". All procedures of cell wounding and cell sorting were controlled using a microscope.

Total RNA was digested with DNAse (Thermo Fisher Scientific, Fermentas Walldorf, Germany) at $37^{\circ} \mathrm{C}$ for 45 min using 1 unit/0.3 $\mu$ g RNA. The concentration and purity of the RNA was estimated with a Nanodrop ND-1000 spectrophotometer (Thermo Fisher Scientific, Fermentas Walldorf, Germany).

First strand complementary DNA (cDNA) synthesis was performed with $0.3 \mu \mathrm{g}$ RNA primed with oligo(dT) $)_{12-18}$ using RevertAid H Minus Reverse Transcriptase (Thermo Fisher Scientific, Fermentas Walldorf, Germany) according to the manufacturer's instructions. The relative expression level of selected genes was monitored by RT-PCR analysis using the DreamTaq Green DNA Polymerase (Thermo Fisher Scientific, Fermentas Walldorf, Germany) [(i) $3 \mathrm{~min}$ at $95^{\circ} \mathrm{C}$; (ii) 25 - 38 amplification cycles: $45 \mathrm{~s}$ at $57^{\circ} \mathrm{C} / 60^{\circ} \mathrm{C}, 45 \mathrm{~s}$ at $72{ }^{\circ} \mathrm{C}, 45 \mathrm{~s}$ at $95^{\circ} \mathrm{C}$; (iii) $45 \mathrm{~s}$ at $57^{\circ} \mathrm{C} / 60^{\circ} \mathrm{C}, 5 \mathrm{~min}$ at $72^{\circ} \mathrm{C}$ ). Also a semi-quantitative analysis of the bands was performed using the GeneTools analysis software (Syngene Bioimaging). As a control for the integrity of the cDNA preparations, $\beta$-actin transcripts were amplified in parallel reactions. The cDNA was also checked for contaminating chromosomal DNA by amplification of a promoter sequence from the $\beta$-actin gene. The specific primer pairs used in this study are listed in Table 2. Primers for Acta2, Cxcl12, and Actb promoter have previously been described [49]. The PCR products were separated on $1.2 \%$ agarose gels and stained with ethidium bromide and visualized under ultraviolet light (254 nm). 


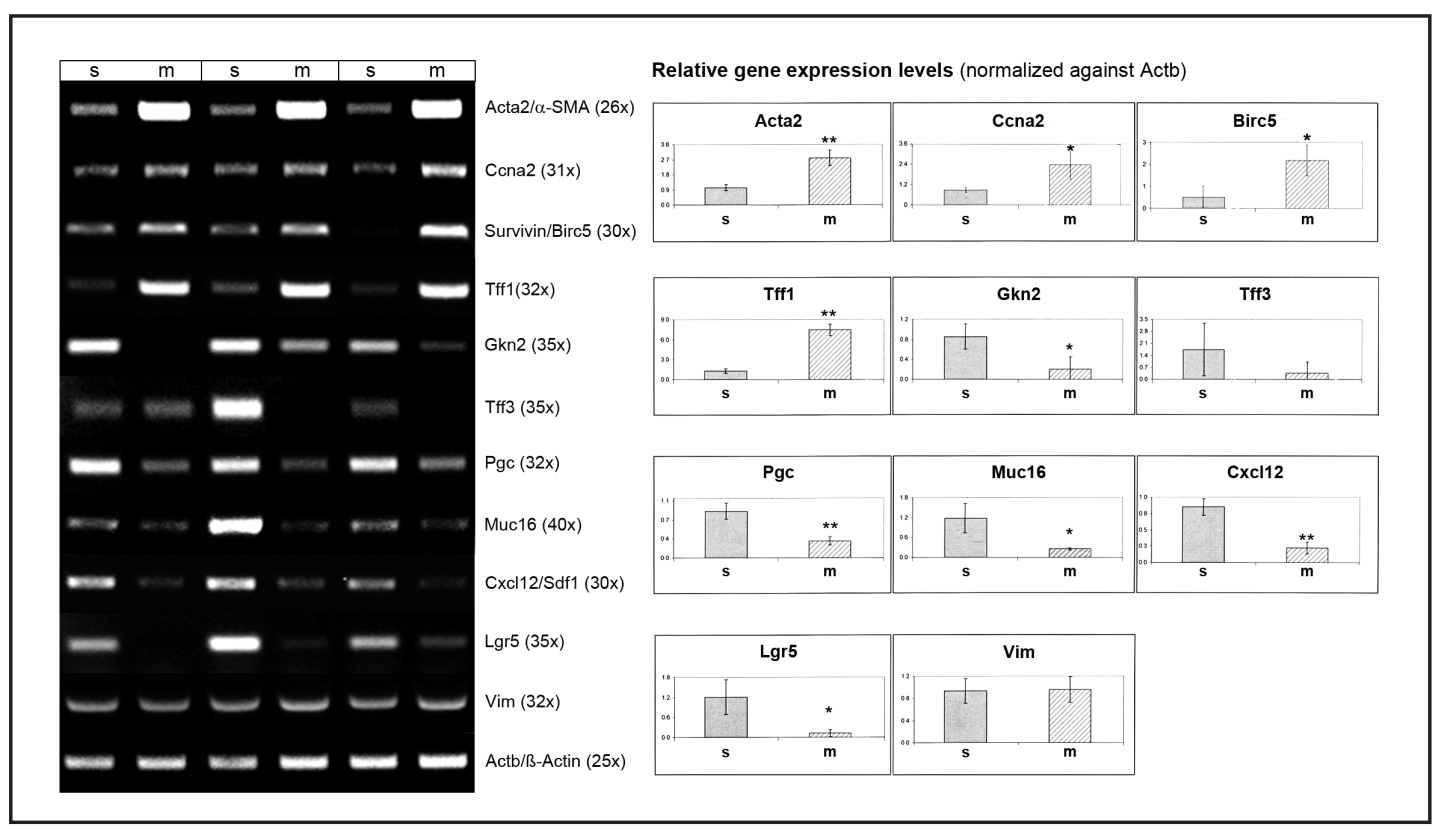

Fig. 1. RT-PCR analysis. $\alpha$-SMA/Acta2, cyclin A2 (Ccna2), survivin/Birc5, Tff1, gastrokine 2 (Gkn2), Tff3, pepsinogen C (Pgc), mucin 16 (Muc16), stromal cell-derived factor-1 (Sdf1/Cxcl12), Lgr 5, and vimentin (Vim) expression was monitored in RGM-1 cells $48 \mathrm{~h}$ after scratch wounding (3 parallel experiments; on the left side). Both the stationary (s) and migratory (m) cells were isolated and analyzed separately. The integrity of the cDNAs was tested by monitoring the transcript levels for $\beta$-actin. The number of amplification cycles is given in parentheses. On the right side, the corresponding semi-quantitative RT-PCR analyses are shown where the transcript levels were normalized against $\beta$-actin (relative gene expression levels). The significance of the differences between stationary and migratory cells is indicated by asterisks.

\section{Statistical analyses}

The statistical analyses using the Student's t-test were performed using the Excel 2003 software package (Microsoft, USA). The error bars in the Figures 1, 2, 4 and 5 represent \pm SEM. Significant differences between the mean values of the different experimental groups are indicated by asterisks $(\mathrm{P} \leq 0.05$ : significant, one asterisk; P $\leq 0.01$ : highly significant, two asterisks; $\mathrm{P} \leq 0.001$ : extremely high significant, three asterisks).

\section{Results}

Expression profiling of stationary and migratory RGM-1 cells

Fig. 1 shows a typical expression profile of separated stationary and migratory RGM1 cells concerning 11 selected genes as well as $\beta$-actin as a control. Many of these genes represent terminal differentiation markers of gastric epithelial cells. As a hallmark, the expression of Tff1 is much stronger in migratory cells when compared with stationary cells. This characteristic pattern is also observed for the expression of $\alpha$-smooth muscle actin $(\alpha-\mathrm{SMA} /$ Acta2) and in a diminished form also for cyclin A2 (Ccna2) and survivin (Birc5). In contrast, the expression of gastrokine 2 (Gkn2), pepsinogen $\mathrm{C}(\mathrm{Pgc})$, stromal cell-derived factor-1 (SDF-1/Cxcl12) and Lgr5 is reduced in migratory cells. Both Tff3 and mucin 16 (Muc16) expression is variable with a tendency to reduction in migratory cells. Vimentin (Vim) and $\beta$-actin (Actb) expression is comparable in stationary and migratory cells.

Because of the elevated Tff1 transcript levels in the migratory RGM-1 cells (Fig. 1) also the Tff1 peptide levels were compared in stationary and migratory cells. Thus, the repopulated zone of migratory cells and the zone of stationary cells were analyzed by the help of immunofluorescence studies $24 \mathrm{~h}$ after scratch wounding (Fig. 2). Generally, strongly 

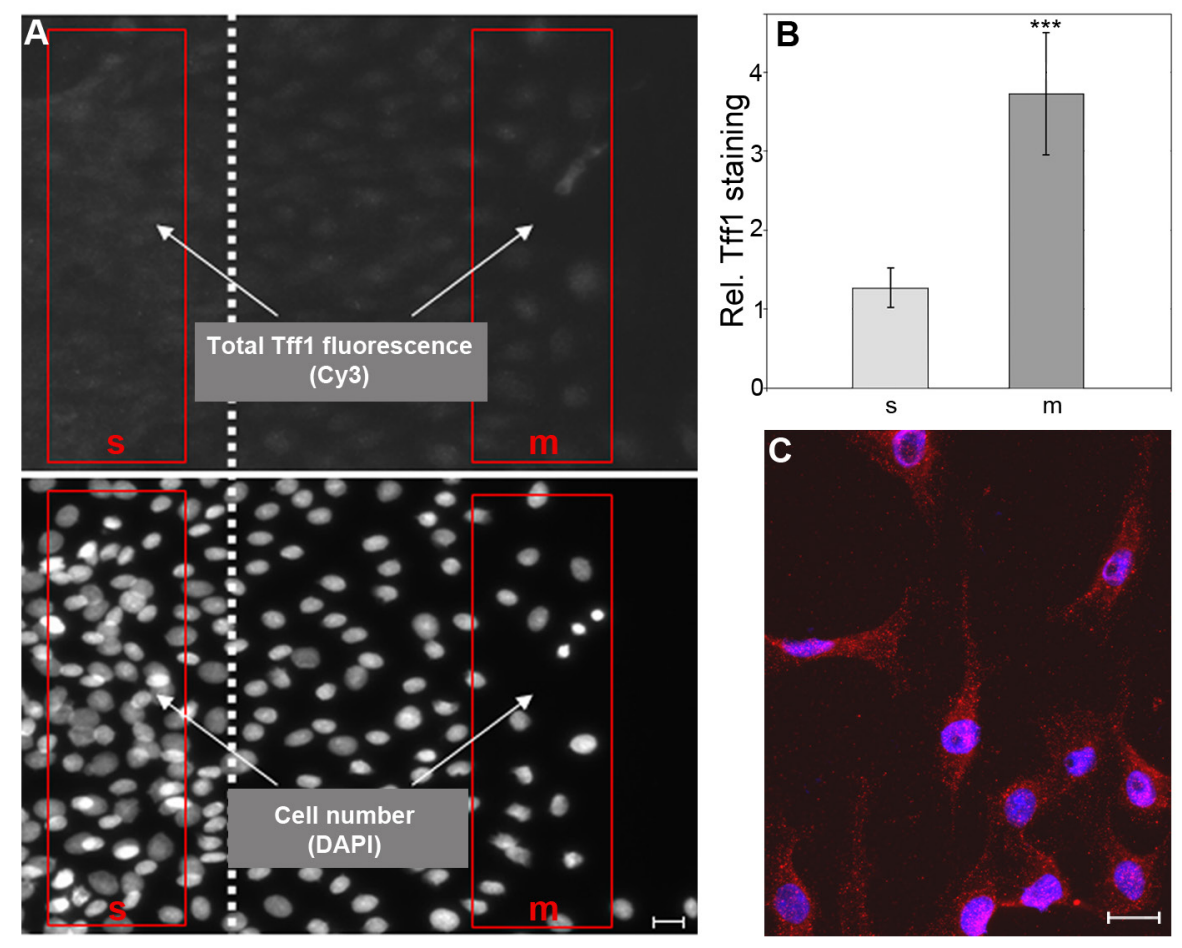

Fig. 2. Localization of Tff1 in stationary and migratory RGM-1 cells. Scratch-wounded RGM-1 cells were allowed to migrate for $24 \mathrm{~h}$. Immunofluorescence with anti-mTff1-1 antiserum and Cy3-labeled secondary antibody; nuclei were counterstained with DAPI. (A) Both the stationary (s) and the migratory zones (m) were imaged and the total Tff1 immunofluorescence was measured within a pair of rectangular standardized areas ( $\mathrm{s}$ and $\mathrm{m}$, respectively). The cell number within these areas was counted after DAPI staining. The scratch wound is indicated by a white dotted line. (B) The relative Tff1 immunofluorescence per cell as calculated in stationary (s) and migratory cells $(\mathrm{m})$. For each group (s, m), 16 pictures from 5 different cover slips were analyzed. The difference between stationary and migratory cells is extremely high significant (P $=5.22 \times 10^{-13}$ ). (C) Typical Tff1 immunofluorescence in migratory cells (Cy3 label, red). Nuclei appear in blue (DAPI). Scale bars in A and C: $20 \mu \mathrm{m}$.

Tff1 positive cells were detected mainly in the migratory zones where Tff 1 is probably localized in secretory granules (Fig. 2C). A semi-quantitative analysis of the relative Tff1 immunoreactivity per cell revealed that Tff 1 staining is mainly localized in migratory RGM-1 cells and that the difference is extremely high significant when compared with stationary cells (Fig. 2B).

Furthermore, the specificity of the antiserum anti-mTff1-1 was tested by Western blot analysis. Clearly, this antiserum detected Tff1 from both the mouse and the rat stomach and the immunoreactivity could be competitively inhibited by the synthetic peptide used for immunization (Fig. 3).

RNA interference targeting Tff1 negatively influences migration of RGM-1 cells

In the past, TFF1 has been reported to act as a motogen in vitro [14, 15, 21]. Because Tff1 expression is mainly restricted to migratory RGM-1 cells (Fig. 1) this is also a strong indication for Tff1 having a role for cell migration. Thus, it was tempting to test whether the inhibition of Tff1 expression with the help of three different RNAi duplexes targeting Tff1 (Tff1-siRNA1, Tff1-siRNA2, Tff1-siRNA3) would affect migration of RGM-1 cells.

RGM-1 cells were transfected with the siRNA duplexes or the negative control siRNA, respectively, and were analyzed after in vitro scratch wounding by counting the repopulated 
Fig. 3. SDS-PAGE under reducing conditions and subsequent Western blot analysis. (A) Extracts of the gastric corpus (C) and antrum (A) from the rat and the mouse, respectively, were analyzed using the affinitypurified anti-mTff1-1 antiserum. (B) Analysis after competition with the synthetic peptide FHPMAIENTQEEECPF. The molecular weight standard is shown on the left.
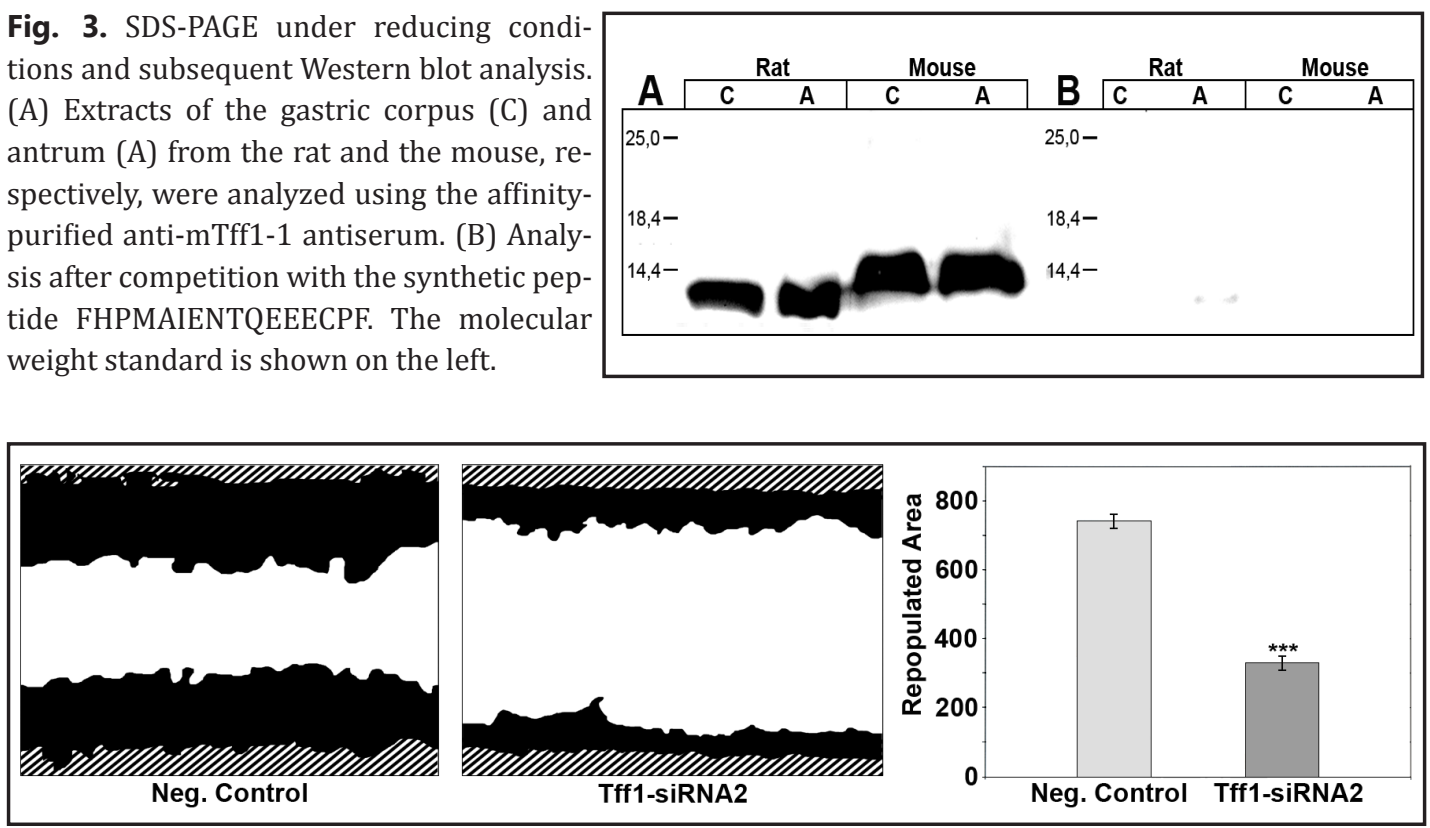

Fig. 4. RNA interference and analysis of cell migration rates. RGM-1 cells treated either with $125 \mathrm{nM}$ stealth $\mathrm{RNAi}^{\mathrm{TM}}$ negative control or $125 \mathrm{nM}$ Tff1-siRNA2 were scratched and allowed to migrate in serum-free medium for $24 \mathrm{~h}$. The wound areas of both the negative control group and the Tff1-siRNA2 group were photographed $0 \mathrm{~h}$ and $24 \mathrm{~h}$ after the scratch at the exactly same positions. Left side: in a typical experiment, the area of the re-populated zone covered with cells is schematically marked in black ( $24 \mathrm{~h}$ ); whereas the stationary cells zone is hatched $(0 \mathrm{~h})$; the non-populated area is shown in white. On the right side, the re-populated areas as calculated by their pixel numbers are shown (for each group 46 photographs from 3 different experiments were analyzed). The difference between the stealth RNAi ${ }^{\mathrm{TM}}$ negative control and Tff1-siRNA2 shows extremely high significance $\left(\mathrm{P}=3.62 \times 10^{-6}\right)$.

area after $24 \mathrm{~h}$. Tff1-siRNA2 was somewhat more active than the other siRNAs. Tff1-siRNA2treated cells showed diminished migratory activity resulting in a smaller repopulated area and this effect was extremely high significant when compared with the negative control (Fig. 4).

Furthermore, the cells transfected with Tff1-siRNA2 were also analyzed by expression profiling of stationary and migratory cells (Fig. 5). Here, Tff1 expression was suppressed when compared with RGM-1 cells transfected with the negative control siRNA. Of note, the expression level of gastrokine 2 was elevated in cells transfected with Tff1-siRNA2; whereas $\alpha$-SMA expression was reduced in these cells and $\beta$-actin expression remained constant.

\section{Discussion}

Expression profiling of stationary and migratory RGM-1 cells: increased Tff1 synthesis in migratory cells

Many of the genes selected for the expression profile (Fig. 1) encode gastric differentiation markers (for reviews, see refs. $[37,38]$ ). Of note, many other known gastric differentiation markers were not detectable (data not shown). Tff2 expression was either very weak or not detectable (data not shown). The expression levels of gastrokine-2 (typical mainly of SMCs), and pepsinogen C (typical of mucous neck and antral gland cells) are downregulated in migratory RGM-1 cells (Fig. 1). This is in line with the expectations for genes, which are characteristic for terminal differentiation [49]. 


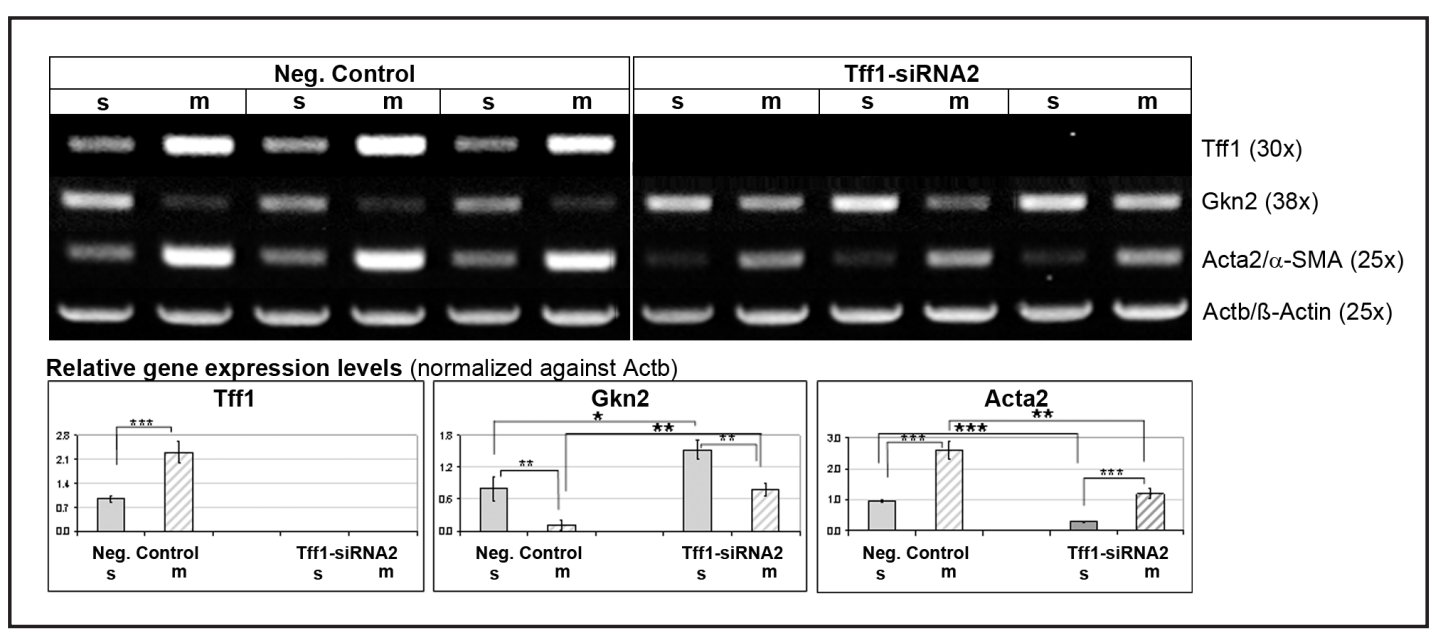

Fig. 5. RT-PCR analysis. RGM-1 cells were pre-treated with the stealth RNAi ${ }^{\mathrm{TM}}$ negative control or Tff1-siRNA2. Then, Tff1, gastrokine 2, and $\alpha$-SMA expression was monitored $24 \mathrm{~h}$ after scratch wounding ( 3 parallel experiments). Both the stationary (s) and migratory $(\mathrm{m})$ cells were isolated and analyzed separately. The integrity of the cDNAs was tested by monitoring the transcript levels s for $\beta$-actin. The number of amplification cycles is given in parentheses. Also shown are semi-quantitative RT-PCR analyses where the transcript levels were normalized against $\beta$-actin (relative gene expression levels). The significance of the differences is indicated by asterisks.

Also down-regulated in migratory RGM-1 cells are the transcript levels of Cxcl12/Sdf1 and Lgr5. SDF- 1 is an $\alpha$-chemokine, which together with its receptor CXCR4 is also typically expressed in various mucous epithelia [53]. This pair contributes to mucosal wound healing by enhancing restitution [54]. Of note, the down-regulation of Sdf1 in migratory RGM-1 cell is comparable with the situation in the non-transformed intestinal cell line IEC-18 [49].

Lgr5 is a stem cell marker typical also of a population of gastric stem cells located mainly at the base of antral glands [55]. The expression of Lgr5 is an indication for the undifferentiated character of the non-transformed RGM-1 cell line. The down-regulation of Lgr5 in migratory cells is reminiscent to the down-regulation of a stem cell marker in migratory IEC-18 cells [49] and it speaks against the acquisition of stem cell characteristics in these migratory cells. As a consequence, this also suggests that migratory RGM-1 cells do not undergo the epithelial-mesenchymal transition (EMT) because EMT has been reported to generate cells with stem cell properties [56]. The view that migratory RGM-1 cells do not undergo EMT is also supported by the vimentin expression profile, which does not differ between stationary and migratory cells (Fig. 1). Increased vimentin expression has been described as a marker for EMT [57]. Also the increased cyclin A2 expression in migratory cells is an indication against EMT [58]. The only hint for maybe a partial EMT might the down-regulation of Muc16 in migratory cells [59]. Generally, the lack of detectable EMT in migratory RGM-1 cells is comparable with the situation in another non-transformed cell line, i.e. IEC-18 [49].

Genes up-regulated in migratory RGM-1 cells are $\alpha$-SMA, cyclin A2, survivin, and Tff1 (Fig. 1). $\alpha$-SMA expression is typical of migratory cells and is associated with the generation of increased contractile forces and stress fiber formation $[49,60]$. Cyclin A2 plays a key role in cell cycle regulation by controlling both the $\mathrm{S}$ phase and the G2/M transition in association with Cdk2 and Cdk1, respectively; furthermore, it also negatively controls cell motility by promoting RhoA activation [61]. Thus, up-regulation of cyclin A2 expression in migratory RGM-1 cells is not expected to enhance cell motility, but is rather due to progression of migratory cells through the cell cycle, whereas cyclin A2 is rather down-regulated in confluent stationary cells $[62,63]$. 
Survivin is expressed predominantly in SMCs [64]. Interestingly, also gastric exfoliated epithelial cells of preterm infants, which are probably SMCs, do express high amount of survivin [65]. In the past, surviving protein was also localized to the nuclei of cultured RGM1 cells [66]. Survivin inhibits apoptosis, regulates cell division, and a role in cell motility has also been described [67]. Survivin is expressed only during mitosis [68]. Thus, up-regulated expression of survivin in migratory cells is perfectly in line with its inhibitor function of apoptosis and regulation of the cell cycle, since cell migration is coupled to a suppression of apoptosis [69].

Tff 1 transcripts are typical of terminally differentiated gastric surface mucous cells and maybe also their precursors [70]. Thus, the up-regulated expression of Tff1 in migratory RGM-1 cells (Fig. 1) is unusual because migratory cells normally lose markers of terminal differentiation [49]. However, this result has been clearly confirmed also on protein level (Fig. 2B). The antiserum anti-mTff1-1 used here recognized also Tff1 from rat stomach on a Western blot analysis and the specificity was demonstrated by competitive inhibition with the synthetic peptide used as antigen (Fig. 3). Also the specificity of the Tff1 immunostaining of RGM-1 cells was positively checked by competitive inhibition (data not shown).

Furthermore, it is somewhat astonishing that the expression levels of Tff1 and gastrokine-2 in stationary versus migratory RGM-1 cells are not parallel but rather contrary (Fig. 1). One would have expected co-expression because human TFF1 has been reported to be able to form disulfide-linked heterodimers with gastrokine-2 [7, 8]. Such a Tff1-Gkn2 heterodimer is also detectable in the rat stomach (data not shown). One explanation for the discrepancy would be that in RGM-1 cells Tff1 exists also in other, different molecular forms (e. g., monomers, homodimers). This assumption is supported by analysis of human TFF1, which gave clear indications for the existence of additional forms $[8,9,10]$.

The reciprocal regulation of Tff1 and Tff3 expression in stationary and migratory RGM1 cells, respectively, might be due to the fact that Tff 1 and Tff 3 are not co-expressed in the gastric mucosa in vivo. In human, TFF1 expression is detectable in terminally differentiated SMCs of both the corpus and the antrum; whereas TFF3 is preferentially expressed in deeper lying SMCs of the gastric antrum (i.e. the proliferative zone) and is hardly detectable in the corpus [70-72]. This special origin might also explain the variable expression of Tff3 in the RGM-1 cell line. Furthermore, TFF1 and TFF3 have probably different molecular functions. Gastric TFF3 forms TFF3-FCGBP heteromers, which are structural mucus components [70, 73]; whereas TFF1 is mainly not associated with gastric mucus [8].

Taken together, the up-regulated expression of Tff1 in migratory RGM-1 cells might be an indication that secretory Tff1 directly supports cell migration by an autocrine/paracrine mechanism. This assumption is in line with the observation that migratory IEC-18 cells up-regulate the expression of genes which support cell migration in many ways, such as plasminogen activator inhibitor-1, transforming growth factor $\alpha$, heparin-binding EGF-like growth factor, ornithine decarboxylase, and $\alpha$-SMA [49].

\section{Tff1 plays a role for restitution in vitro}

In order to test this concept functionally, RGM-1 cells were transfected with three different siRNA duplexes targeting Tff1 and scratch wounding assays were performed. All three siRNA duplexes reduced in vitro restitution with Tff1-siRNA2 being somewhat more active (extremely high significance, Fig. 4). This effect increased with the concentration of the siRNA duplexes (data not shown). Tff1 expression was dramatically reduced in these cells as expected (Fig. 5). Interestingly, also $\alpha$-SMA expression was significantly downregulated in Tff1-siRNA2 transfected cells indicating that the differentiation of RGM-1 cells into a migratory phenotype was negatively affected by Tff1-siRNA2 (Fig. 5).

Lowering endogenous Tff1 in RGM-1 cells strongly decreased their migration. This result is in agreement with that of TFF1 knockdown experiments using shRNA analyzing the migration of MCF7 and ZR75.1 cells in Transwell chambers [21]. Taken together, Tff1 is a motogenic factor, which probably has a function in vivo during restitution of the gastric mucosa by SMCs and also during self-renewal. Particularly, a possible up-regulation of TFF1 
Fu/Kalbacher/Hoffmann: TFF1 and Cell Migration

synthesis in migratory SMCs also in vivo would be an ideal mechanism to specifically enhance restitution only where topologically needed and to minimize eventual negative side effects of TFF1 such as cell scattering and invasiveness.

\section{Acknowledgements}

We thank Dr. S. J. Hagen (Boston) for kindly providing RGM-1 cells, Dr. E. B. Znalesniak for her valuable help during the early phases of this project, E. Voß for secretarial assistance, and Dr. J. Lindquist for careful proofreading of the manuscript.

\section{References}

1 Ribieras S, Tomasetto C, Rio MC: The pS2/TFF1 trefoil factor, from basic research to clinical applications. Biochim Biophys Acta 1998;1378:F61-F77.

-2 Tomasetto C, Rio MC: Pleiotropic effects of trefoil factor 1 deficiency. Cell Mol Life Sci 2005;62:2916-2920.

3 Kjellev S: The trefoil factor family - small peptides with multiple functionalities. Cell Mol Life Sci 2009;66:1350-1369.

4 Hoffmann W: TFF peptides; in Kastin AJ (ed): Handbook of biologically active peptides (2 $2^{\text {nd }}$ edition). San Diego, Elsevier, 2013, pp1338-1345.

-5 Rio MC, Bellocq JP, Daniel JY, Tomasetto C, Lathe R, Chenard MP, Batzenschlager A, Chambon P: Breast cancer-associated pS2 protein: synthesis and secretion by normal stomach mucosa. Science 1988;241:705708.

-6 Hanby AM, Poulsom R, Singh S, Elia G, Jeffery RE, Wright NA: Spasmolytic polypeptide is a major antral peptide: distribution of the trefoil peptides human spasmolytic polypeptide and pS2 in the stomach. Gastroenterology 1993;105:1110-1116.

7 Westley BR, Griffin SM, May FE: Interaction between TFF1, a gastric tumor suppressor trefoil protein, and TFIZ1, a brichos domain-containing protein with homology to SP-C. Biochemistry 2005;44:7967-7975.

8 Kouznetsova I, Laubinger W, Kalbacher H, Kalinski T, Meyer F, Roessner A, Hoffmann W: Biosynthesis of gastrokine-2 in the human gastric mucosa: restricted spatial expression along the antral gland axis and differential interaction with TFF1, TFF2 and mucins. Cell Physiol Biochem 2007;20:899-908.

-9 Chadwick M.P, Westley BR, May FE: Homodimerization and hetero-oligomerization of the single-domain trefoil protein pNR-2/pS2 through cysteine 58. Biochem J 1997;327:117-123.

10 Newton JL, Allen A, Westley BR, May FE: The human trefoil peptide, TFF1, is present in different molecular forms that are intimately associated with mucus in normal stomach. Gut 2000;46:312-320.

-11 Kannan R, Tomasetto C, Staub A, Bossenmeyer-Pourie C, Thim L, Nielsen PF, Rio M: Human pS2/trefoil factor 1: production and characterization in Pichia pastoris. Protein Expr Purif 2001;21:92-98.

12 Chadwick MP, May FE, Westley BR: Production and comparison of mature single-domain 'trefoil' peptides pNR-2/pS2 Cys58 and pNR-2/pS2 Ser58. Biochem J 1995;308:1001-1007.

13 Williams MA, Westley BR, May FE, Feeney J: The solution structure of the disulphide-linked homodimer of the human trefoil protein TFF1. FEBS Lett 2001;493:70-74.

-14 Marchbank T, Westley BR, May FE, Calnan DP, Playford RJ: Dimerization of human pS2 (TFF1) plays a key role in its protective/healing effects. J Pathol 1998;185:153-158.

15 Prest SJ, May FE, Westley BR: The estrogen-regulated protein, TFF1, stimulates migration of human breast cancer cells. FASEB J 2002;16:592-594.

16 Bossenmeyer-Pourie C, Kannan R, Ribieras S, Wendling C, Stoll I, Thim L, Tomasetto C, Rio MC: The trefoil factor 1 participates in gastrointestinal cell differentiation by delaying G1-S phase transition and reducing apoptosis. J Cell Biol 2002;157:761-770.

17 Weise A, Dunker N: High trefoil factor 1 (TFF1) expression in human retinoblastoma cells correlates with low growth kinetics, increased cyclin-dependent kinase (CDK) inhibitor levels and a selective downregulation of CDK6. Histochem Cell Biol 2013;139:323-338. 
18 Rodrigues S, Van Aken E, Van Bocxlaer S, Attoub S, Nguyen QD, Bruyneel E, Westley BR, May FEB, Thim L, Mareel M, Gespach C, Emami S: Trefoil peptides as proangiogenic factors in vivo and in vitro: implication of cyclooxygenase-2 and EGF receptor signaling. FASEB J 2003;17:7-16.

19 Williams R, Stamp GW, Gilbert C, Pignatelli M, Lalani EN: pS2 transfection of murine adenocarcinoma cell line 410.4 enhances dispersed growth pattern in a 3-D collagen gel. J Cell Sci 1996;109:63-71.

20 Emami S, Le Floch N, Bruyneel E, Thim L, May F, Westley B, Rio MC, Mareel M, Gespach C: Induction of scattering and cellular invasion by trefoil peptides in src- and RhoA-transformed kidney and colonic epithelial cells. FASEB J 2001;15:351-361.

21 Buache E, Etique N, Alpy F, Stoll I, Muckensturm M, Reina-San-Martin B, Chenard MP, Tomasetto C, Rio MC: Deficiency in trefoil factor 1 (TFF1) increases tumorigenicity of human breast cancer cells and mammary tumor development in TFF1-knockout mice. Oncogene 2011;30:3261-3273.

22 Rodrigues S, Rodrigue CM, Attoub S, Flejou JF, Bruyneel E, Bracke M, Emami S, Gespach C: Induction of the adenoma-carcinoma progression and Cdc25A-B phosphatases by the trefoil factor TFF1 in human colon epithelial cells. Oncogene 2006;25:6628-6636.

23 Emami S, Rodrigues S, Rodrigue CM, Le Floch N, Rivat C, Attoub S, Bruyneel E, Gespach C: Trefoil factor family (TFF) peptides and cancer progression. Peptides 2004;25:885-898.

24 Perry JK, Kannan N, Grandison PM, Mitchell MD, Lobie PE: Are trefoil factors oncogenic? Trends Endocrin Metab 2008;19:74-81.

25 Lefebvre O, Chenard MP, Masson R, Linares J, Dierich A, LeMeur M, Wendling C, Tomasetto C, Chambon P, Rio MC: Gastric mucosa abnormalities and tumorigenesis in mice lacking the pS2 trefoil protein. Science 1996;274:259-262.

26 Soutto M, Belkhiri A, Piazuelo MB, Schneider BG, Peng D, Jiang A, Washington MK, Kokoye Y, Crowe SE, Zaika A, Correa P, Peek RM Jr, El-Rifai W: Loss of TFF1 is associated with activation of NF- $\kappa$ B-mediated inflammation and gastric neoplasia in mice and humans. J Clin Invest 2011;121:1753-1767.

-27 Saukkonen K, Tomasetto C, Narko K, Rio MC, Ristimaki A: Cyclooxygenase-2 expression and effect of celecoxib in gastric adenomas of trefoil factor 1-deficient mice. Cancer Res 2003;63:3032-3036.

28 Karam SM, Tomasetto C, Rio MC: Trefoil factor 1 is required for the commitment programme of mouse oxyntic epithelial progenitors. Gut 2004;53:1408-1415.

29 Karam SM, Tomasetto C, Rio MC: Amplification and invasiveness of epithelial progenitors during gastric carcinogenesis in trefoil factor 1 knockout mice. Cell Prolif 2008;41:923-935.

30 Hoffmann W: TFF (trefoil factor family) peptides and their potential roles for differentiation processes during airway remodeling. Curr Med Chem 2007;14:2716-2719.

- 31 Torres LF, Karam SM, Wendling C, Chenard MP, Kershenobich D, Tomasetto C, Rio MC: Trefoil factor 1 (TFF1/pS2) deficiency activates the unfolded protein response. Mol Med 2002;8:273-282.

-32 Playford RJ, Marchbank T, Goodlad RA, Chinery RA, Poulsom R, Hanby AM: Transgenic mice that overexpress the human trefoil peptide pS2 have an increased resistance to intestinal damage. Proc Natl Acad Sci USA 1996;93:2137-2142.

-33 Vandenbroucke K, Hans W, Van Huysse J, Neirynck S, Demetter P, Remaut E, Rottiers P, Steidler L: Active delivery of trefoil factors by genetically modified Lactococcus lactis prevents and heals acute colitis in mice. Gastroenterology 2004;127:502-513.

-34 Katoh M: Trefoil factors and human gastric cancer (review). Int J Mol Med 2003;12:3-9.

- 35 Rio MC, Chenard MP, Wolf C, Marcellin L, Tomasetto C, Lathe R, Bellocq JP, Chambon P: Induction of pS2 and hSP genes as markers of mucosal ulceration of the digestive tract. Gastroenterology 1991;100:375-379.

- 36 Wright NA, Poulsom R, Stamp G, Van Noorden S, Sarraf C, Elia G, Ahnen D, Jeffery R, Longcroft J, Pike C: Trefoil peptide gene expression in gastrointestinal epithelial cells in inflammatory bowel disease. Gastroenterology 1993;104:12-20.

- 37 Hoffmann W: Stem cells, self-renewal and cancer of the gastric epithelium. Curr Med Chem 2012;19:59755983.

38 Hoffmann W: Self-renewal of the gastric epithelium from stem and progenitor cells. Front Biosci (Scholar) 2013;S5:720-731.

-39 Silen W, Ito S: Mechanisms for rapid re-epithelialization of the gastric mucosal surface. Annu Rev Physiol 1985;47:217-229.

40 Lacy ER: Rapid epithelial restitution in the stomach: an updated perspective. Scand J Gastroenterol 1995;30 Suppl 210:6-8. 
41 Wallace JL, Granger DN: The cellular and molecular basis of gastric mucosal defense. FASEB J 1996;10:731740 .

42 Jones MK, Tomikawa M, Mohajer B, Tarnawski AS: Gastrointestinal mucosal regeneration: role of growth factors. Front Biosci 1999;4:D303-309.

43 Cheng AM, Morrison SW, Yang DX, Hagen SJ: Energy dependence of restitution in the gastric mucosa. Am J Physiol 2001;281:C430-C438.

44 Hoffmann W: Trefoil factors TFF (trefoil factor family) peptide-triggered signals promoting mucosal restitution. Cell Mol Life Sci 2005;62:2932-2938.

45 Kobayashi I, Kawano S, Tsuji S, Matsui H, Nakama A, Sawaoka H, Masuda E, Takei Y, Nagano K, Fusamoto H, Ohno T, Fukutomi H, Kamada T: RGM1, a cell line derived from normal gastric mucosa of rat. In Vitro Cell Dev Biol-Animal 1996;32:259-261.

46 Nakamura E, Takahashi S, Matsui H, Okabe S: Interleukin-1 beta inhibits growth factor-stimulated restoration of wounded rat gastric epithelial cell monolayers. Digest Dis Sci 1998;43:476-484.

- 47 Osada T, Watanabe S, Tanaka H, Hirose M, Miyazaki A, Sato N: Effect of mechanical strain on gastric cellular migration and proliferation during mucosal healing: role of Rho dependent and Rac dependent cytoskeletal reorganisation. Gut 1999;45:508-515.

48 Ragasa R, Nakamura E, Marrone L, Yanaka S, Hayashi S, Takeuchi K, Hagen SJ: Isothiocyanate inhibits restitution and wound repair after injury in the stomach: Ex vivo and in vitro studies. J Pharmacol Exp Therap 2007;323:1-9.

-49 Znalesniak EB, Dürer U, Hoffmann W: Expression profiling of stationary and migratory intestinal epithelial cells after in vitro wounding: restitution is accompanied by cell differentiation. Cell Physiol Biochem 2009;24:125-132.

50 Wiede A, Jagla W, Welte T, Köhnlein T, Busk H, Hoffmann W: Localization of TFF3, a new mucus-associated peptide of the human respiratory tract. Am J Respir Crit Care Med 1999;159:1330-1335.

-51 Carstea ED, Hough S, Wiederholt K, Welch PJ: State-of-the-art modified RNAi compounds for therapeutics. IDrugs 2005;8:642-647.

-52 Dürer U, Hartig R, Bang S, Thim L, Hoffmann W: TFF3 and EGF induce different migration patterns of intestinal epithelial cells in vitro and trigger increased internalization of E-cadherin. Cell Physiol Biochem 2007;20:329-346.

-53 Agace WW, Amara A, Roberts A.I, Pablos JL, Thelen S, Uguccioni M, Li XY, Marsal J, Arenzana-Seisdedos F, Delaunay T, Ebert EC, Moser B, Parker CM: Constitutive expression of stromal derived factor-1 by mucosal epithelia and its role in HIV transmission and propagation. Curr Biol 2000;10:325-328.

54 Smith JM, Johanesen PA, Wendt MK, Binion DG, Dwinell MB: CXCL12 activation of CXCR4 regulates mucosal host defense through stimulation of epithelial cell migration and promotion of intestinal barrier integrity. Am J Physiol 2005;288:G316-G326.

-55 Barker N, Huch M, Kujala P, van de Wetering M, Snippert HJ, van Es JH, Sato T, Stange DE, Begthel H, van den Born M, Danenberg E, van den Brink S, Korving J, Abo A, Peters PJ, Wright N, Poulsom R, Clevers H: Lgr5(+ve) stem cells drive self-renewal in the stomach and build long-lived gastric units in vitro. Cell Stem Cell 2010;6:25-36.

-56 Mani SA, Guo W, Liao MJ, Eaton EN, Ayyanan A, Zhou AY, Brooks M, Reinhard F, Zhang CC, Shipitsin M, Campbell LL, Polyak K, Brisken C, Yang J, Weinberg RA: The epithelial-mesenchymal transition generates cells with properties of stem cells. Cell 2008;133:704-715.

-57 Kalluri R, Weinberg RA: The basics of epithelial-mesenchymal transition. J Clin Invest 2009;119:14201428.

58 Bendris N, Arsic N, Lemmers B, Blanchard JM: Cyclin A2, Rho GTPases and EMT. Small GTPases 2012;3:225-228.

-59 Comamala M, Pinard M, Theriault C, Matte I, Albert A, Boivin M, Beaudin J, Piche A, Rancourt C: Downregulation of cell surface CA125/MUC16 induces epithelial-to-mesenchymal transition and restores EGFR signalling in NIH:OVCAR3 ovarian carcinoma cells. Brit J Cancer 2011;104:989-999.

60 Znalesniak EB, Hoffmann W: Modulation of cell-cell contacts during intestinal restitution in vitro and effects of epidermal growth factor (EGF). Cell Physiol Biochem 2010;25:533-542.

61 Arsic N, Bendris N, Peter M, Begon-Pescia C, Rebouissou C, Gadea G, Bouquier N, Bibeau F, Lemmers B, Blanchard JM: A novel function for cyclin A2: control of cell invasion via RhoA signaling. J Cell Biol 2012;196:147-162. 
Fu/Kalbacher/Hoffmann: TFF1 and Cell Migration

62 Watanabe S, Hirose M, Yasuda T, Miyazaki A, Sato N: Role of actin and calmodulin in migration and proliferation of rabbit gastric mucosal cells in culture. J Gastroenterol Hepatol 1994;9:325-333.

63 Zahm JM, Kaplan H, Herard AL, Doriot F, Pierrot D, Somelette P, Puchelle E: Cell migration and proliferation during the in vitro wound repair of the respiratory epithelium. Cell Motil Cytoskel 1997;37:33-43.

64 Chiou SK, Moon WS, Jones MK, Tarnawski AS: Survivin expression in the stomach: implications for mucosal integrity and protection. Biochem Biophys Res Commun 2003;305:374-379.

65 Kaeffer B: Survival of exfoliated epithelial cells: a delicate balance between anoikis and apoptosis. J Biomed Biotechnol 2011;2011:534139.

-66 Chiou SK, Tanigawa T, Akahoshi T, Abdelkarim B, Jones MK, Tarnawski A.S: Survivin: A novel target for indomethacin-induced gastric injury. Gastroenterology 2005;128:63-73.

-67 Mckenzie JA, Grossman D: Role of the apoptotic and mitotic regulator survivin in melanoma. Anticancer Res 2012;32:397-404.

68 Waligorska-Stachura J, Jankowska A, Wasko R, Liebert W, Biczysko M, Czarnywojtek A, Baszko-Blaszyk D, Shimek V, Ruchala M: Survivin - prognostic tumor biomarker in human neoplasms - review. Ginekol Pol 2012;83:537-540.

69 Cho SY, Klemke RL: Extracellular-regulated kinase activation and CAS/Crk coupling regulate cell migration and suppress apoptosis during invasion of the extracellular matrix. J Cell Biol 2000;149:223-236.

70 Kouznetsova I, Kalinski T, Meyer F, Hoffmann W: Self-renewal of the human gastric epithelium: new insights from expression profiling using laser microdissection. Mol Biosyst 2011;7:1105-1112.

71 Kouznetsova I, Peitz U, Vieth M, Meyer F, Vestergaard EM, Malfertheiner P, Roessner A, Lippert H, Hoffmann W: A gradient of TFF3 (trefoil factor family 3) peptide synthesis within the normal human gastric mucosa. Cell Tissue Res 2004;316:155-165.

72 Kouznetsova I, Kalinski T, Peitz U, Mönkemüller KE, Kalbacher H, Vieth M, Meyer F, Roessner A, Malfertheiner P, Lippert H, Hoffmann W: Localization of TFF3 peptide in human esophageal submucosal glands and gastric cardia: differentiation of two types of gastric pit cells along the rostro-caudal axis. Cell Tissue Res 2007;328:365-374.

73 Albert TK, Laubinger W, Müller St, Hanisch F-G, Kalinski T, Meyer F, Hoffmann W: Human intestinal TFF3 forms disulfide-linked heteromers with the mucus-associated FCGBP protein and is released by hydrogen sulphide. J Proteome Res 2010;9:3108-3117. 